\title{
Filantropi Islam Untuk \\ Pemberdayaan Ekonomi Umat \\ (Model Pemberdayaan ZISWAF di BMT \\ Se-Kabupaten Demak)
}

\author{
Abdurrohman Kasdi \\ Prodi Ekonomi Syariah, STAIN Kudus \\ abdurrahmankasdi@gmail.com
}

\begin{abstract}
Abstrak
Filantropi Islam merupakan praktik kedermawanan dalam tradisi Islam melalui zakat, infak, sedekah, dan wakaf (ZISWAF). Sebagai lembaga keuangan mikro syari'ah yang juga bergerak dalam filantropi Islam, BMT sangat berperan strategis dalam pembinaan agama bagi para nasabah dan penerima ZISWAF. Karena BMT merupakan lembaga yang di dalamnya mempunyai dua orientasi sekaligus; berorientasi laba dan nirlaba. BMT, yang salah satu perannya sebagai Bait alMal dalam konteks ini adalah lembaga keuangan yang kegiatannya mengelola dana yang bersifat nirlaba (sosial) yang sumber dananya diperoleh dari ZISWAF. Selanjutnya dana tersebut diserahkan kepada mustahiq. Dengan demikian, pemberdayaan ekonomi yang dilakukan oleh BMT tidak terbatas pada sisi ekonomi dan kehidupan materiil saja, melainkan juga pada sisi agama dan kehidupan spiritualnya. Hasil penelitian menunjukkan bahwa ada tiga sistem pengelolaan ZISWAF yang dilakukan pengelola BMT se-Kabupaten Demak, yaitu: sistem pengelolaan satu arah, sistem pengelolaan umpan balik (feed back), dan dengan sistem pilot project. Sedangkan model pemberdayaan ZISWAF yang dilakukan oleh pengelola BMT adalah: pemberdayaan sosial dengan cara penyaluran dana untuk fakir miskin langsung, pemberdayaan untuk pengembangan sumber daya manusia, dan dengan model pemberdayaan ekonomi melalui mudharabah muqayyadah, wadi'ah muqayyadah dan pemberdayaan dengan pinjaman lunak tanpa bagi hasil.
\end{abstract}

Kata Kunci: Filantropi Islam, Bait al-Mal, Pemberdayaan, Ekonomi Umat 


\begin{abstract}
The practical of Islamic philanthropy in the Islamic tradition is through zakat, donation, charity, and waqf (ZISWAF). BMT as Islamic microfinance institutions is also engaged in the Islamic philanthropy, BMT very strategic role in religious guidance to our customers and recipients of ZISWAF. Because BMT is an institution in which has two orientations at once; for-profit and non-profit. BMT, whose role as one of Bait al-Mal in this context is a financial institution that manages funds activities that are non-profit (social) in which the funds obtained from ZISWAF, then the funds were give to the receivers (mustahiq). Thus, economic empowerment carried out by BMT are not limited to the economic and material life, but also in terms of religion and spiritual life. The results showed that there are three ZISWAF management system conducted BMT managers in Demak regency, namely: a one-way system management, feedback management system and the system pilot project. While empowerment ZISWAF model performed by BMT managers are: social empowerment by way of channeling funds to the poor directly, empowerment for human resource development, and the model of economic empowerment through mudaraba muqayyadah, wadi'ah muqayyadah and empowerment with a soft loan without profit sharing.
\end{abstract}

Keywords: Islamic Philanthropy, Bait al-Mal, Empowerment, Economic Ummat

\title{
PENDAHULUAN
}

Di tengah gencarnya pembangunan nasional dan upaya peningkatan kesejahteraan masyarakat, kita masih sering menjumpai ketimpangan di masyarakat; masih tingginya angka kemiskinan, kesehatan dan lingkungan yang buruk, birokrasi yang korup, layanan publik yang tidak memadai serta rendahnya taraf hidup masyarakat. Kehidupan sosial belum sungguhsungguh mencerminkan kesejahteraan sebagaimana yang diamanatkan konstitusi dan ajaran agama. Padahal potensi dana filantropi sangat besar untuk mengatasi problematika tersebut. 
Ajaran Islam juga sering menyinggung tentang anjuran berfilantropi, agar tidak terjadi kesenjangan antara orang kaya dan orang miskin. Demikian juga, kedermawanan umat Islam menyimpan potensi yang sangat besar dalam pengembangan filantropi Islam.

Fenomena inilah yang menjadikan kajian tentang filantropi Islam yang dikaitkan dengan pemberdayaan ekonomi umat menjadi penting. Dengan mengambil telaah tentang pengelolaan ZISWAF di BMT se-Kabupaten Demak, diharapkan dapat menganalisispotensi filantropi Islam yang dapat menjadi modal sosial untuk membangun civil society yang kokoh dan bermartabat. Karena tradisi ini bukan hanya mencerminkan suatu bentuk ketaatan dalam beragama, melainkan juga menjadi bagian tak terpisahkan dari perkembangan masyarakat Muslim dari segi sosial, budaya, dan politik.

\section{KAJIAN LITERATUR}

\section{ZISWAF Sebagai Manifestasi Filantropi Islam}

Istilah filantropi diartikan dengan rasa kecintaan kepada manusia yang terpatri dalam bentuk pemberian derma kepada orang lain (Ilchman, 2006). Filantropi juga dimaknai sebagai konseptualisasi dari praktik pemberian sumbangan sukarela (voluntary giving), penyediaan layanan sukarela (voluntary services) dan asosiasi sukarela (voluntary association) secara suka rela untuk membantu pihak lain yang membutuhkan sebagai ekspresi rasa cinta. Filantropi dalam arti pemberian derma biasa juga disamakan dengan istilah karitas (charity) (Kim Klein, 2001).

Adapun istilah filantropi yang dikaitkan dengan Islam menunjukkan adanya praktik filantropi dalam tradisi Islam melalui zakat, infak, sedekah, dan wakaf (Abu Zahrah, 2005). Istilah ini dapat membantu membawa wacana kedermawanan Islam ke dalam sebuah diskursus yang dapat menjangkau isu-isu yang lebih luas. Tidak hanya melihat masalahnya dari segi wacana tradisional saja, seperti fikih dan etika Islam, melainkan juga dapat mengkaitkan dengan isu-isu keadilan sosial, kesejahteraan umat, masyarakat madani, kebijakan publik, tata kelola yang baik dan manajemen yang profesional. 
Islam menganjurkan seorang Muslim untuk berfilantropi agar harta kekayaan tidak hanya berputar di antara orang-orang kaya (QS. al-Hasyr: 7). Ketika menerangkan filantropi, alQur'an sering menggunakan istilah zakat, infak dan sedekah yang mengandung pengertian berderma.Kedermawanan dalam Islam, yang mencakup dimensi-dimensi kebaikan secara luas seperti zakat, infak, sedekah, dan wakaf merupakan istilahistilah yang menunjukkan bentuk resmi filantropi Islam. Sistem filantropi Islam ini kemudian dirumuskan oleh para fuqaha dengan banyak bersandar pada al-Qur'an dan hadits Nabi mengenai ketentuan terperinci, seperti jenis-jenis harta, kadar minimal, jumlah, serta aturan yang lainnya.

Al-Qur'an tidak mengintrodusir istilah zakat, tetapi sedekah. Namun, pada tatanan diskursus penggunaan istilah zakat, infak dan sedekah terkadang juga mengandung makna yang khusus dan juga digunakan secara berbeda (QS. at-Taubah: 60).Zakat sering diartikan sebagai pengeluaran harta yang sifatnya wajib dan salah satu dari rukun Islam serta berdasarkan pada perhitungan tertentu. Infak sering merujuk kepada pemberian yang bukan zakat, yang kadangkala jumlahnya lebih besar atau lebih kecil dari zakat dan biasanya untuk kepentingan umum. Misalnya bantuan untuk mushalla, masjid, madrasah dan pondok pesantren. Sedekah biasanya mengacu pada derma yang kecil-kecil jumlahnya yang diserahkan kepada orang miskin, pengemis, pengamen, dan lain-lain. Sedangkan wakaf hampir sama dengan infak, tetapi mempunyai unsur kekekalan manfaatnya; tidak boleh diperjualbelikan dan tidak boleh diwariskan (Ridwan al-Makassari, 2006).

Urgensi filantropi dalam Islam dapat dilihat dari cara alQur'an menekankan keseimbangan antara mengeluarkan zakat dan menegakkan shalat. Begitu tegasnya perintah mengenai zakat, al-Qur'an mengulang sebanyak 72 kali perintah zakat (ita' az-zakat) dan menggandengkannya dengan perintah shalat (iqam ash-shalat). Kata infak dengan berbagai bentuk derivasinya muncul sebanyak 71 kali dan kata sedekah muncul sebanyak 24 kali yang menunjukkan arti dan aktivitas filantropi Islam. Ajaran shalat merupakan rukun Islam yang utama dan pengamalan zakat dinilai setara dengan pelaksanaan shalat (QS. al-Baqarah: 177). 


\section{HASIL DAN PEMBAHASAN}

\section{Profil BMT Objek Penelitian}

Baitul Mal wat Tamwil merupakan gabungan dari kata Arab Bait al-Mal dan Bait at-Tamwil. Bait al-Mal dalam konteks ini adalah lembaga keuangan yang kegiatannya mengelola dana yang bersifat nirlaba (sosial) yang sumber dananya diperoleh dari ZISWAF, atau sumber lain yang halal. Selanjutnya dana tersebut diserahkan kepada mustahiq (orang yang berhak). Karena sifat kegiatannya yang sama dengan LAZIS, maka berdasarkan UU No. 38 Tahun 1999 tentang zakat, sebagian BMT mendapatkan pengesahan dari pemerintah setempat sebagai LAZIS.Sedangkan Bait at-Tamwil adalah lembaga keuangan yang kegiatannya menghimpun dan menyalurkan dana masyarakat yang berorientasi laba. Penghimpunan dananya diperoleh melalui simpanan pihak ketiga dan penyalurannya dilakukan dalam bentuk pembiayaan atau investasi, yang dijalankan berdasarkan prinsip syari'ah (Bamualim, 2005).

Dengan demikian, BMT merupakan lembaga yang didalamnya mempunyai dua kegiatan sekaligus; satu lembaga berorientasi laba dan yang lainnya nirlaba. Namun pada umumnya secara opersional keduanya merupakan badan yang terpisah. Sistem pengelolaan dana kedua badan tersebut tidak bercampur satu sama lain dan penilaian kinerjanya pun dilakukan secara terpisah (Widodo Ak. dkk., 1999). Berbeda dengan Bank Syariah yang ukurannya besar dan mempunyai akses kepada pasar uang, BMT merupakan lembaga keuangan mikro syari'ah yang didirikan dengan semangat kekeluargaan dan beroperasi berdasarkan prinsip bagi hasil (loss and profit sharing) yang dikenal sebagai sistem syari'ah.

BMT melakukan dua jenis akad dalam menyalurkan dananya, yakni akad pembiayaan dengan sistem bagi hasil dan akad jual beli dengan pembayaran ditangguhkan. Untuk pembiayaan dengan sistem bagi hasil, transaksi yang dilakukan adalah musyarakah dan mudharabah. Sedangkan untuk jual beli dengan pembayaran ditangguhkan, bentuk transaksi yang diterapkan adalah murabbahah dan bai' bi tsaman 'ajil.

Sebagai lembaga keuangan mikro syari'ah yang juga bergerak dalam filantropi Islam, BMT sangat berperan dalam 
pembinaan agama bagi para nasabah dan penerima ZISWAF. Dengan demikian, pemberdayaan ekonomi yang dilakukan oleh BMT tidak terbatas pada sisi ekonomi dan kehidupan materil masyarakat akar rumput, melainkan juga pada sisi agama dan kehidupan spriritualnya. Dalam konteks ini, BMT Kabupaten Demak yang menjadi objek penelitian ini adalah:

\section{Pertama, BMT MADE (Masjid Agung}

Demak).Berdirinya BMT MADE ini berawal dari Program Pelatihan Pengangguran Pekerja Terampil yang diselenggarakan oleh Departemen Tenaga Kerja Jawa Tengah bekerjasama dengan LSM Pinbuk Jawa Tengah Tahun 1998 yang diadakan di Asrama Haji Donohudan. Pelatihan ini kemudian ditindaklanjuti dengan pertemuan pemuda yang diketuai oleh Ariful Husni, Ketua BKM Kabupaten Demak H. Moh. Zaini Dahlan, dan Ketua Takmir Masjid Agung Demak KHA. Soehaimi Soelaiman yang sepakat untuk mendirikan BMT MADE (Profil BMT MADE, 2016).

Secara Resmi, BMT MADE berdiri pada tanggal 03 Oktober 1998 yang diresmikan oleh Bupati Demak saat itu, H. Djoko Widji Suwito, S.IP di Gedung DPRD Kabupaten Demak. Selanjutnya, pada tanggal 23 Oktober 1998 ijin Badan Hukum diajukan dan keluar ijinnya pada tanggal 02 Nopember 1998, dengan SK Badan Hukum nomor: 06/BH/KDK.11-03/XI/98 oleh Departemen Koperasi Pengusaha Kecil dan Menengah RI. Sejak turunnya SK Badan Hukum ini, BMT MADE mulai beroperasi dengan tujuan pemberdayaan ekonomi umat di Kabupaten Demak khususnya dan Jawa Tengah pada umumnya. Sampai sekarang perkembangan BMT MADE sangat pesat, baik yang terkait pertumbuhan, pelayanan maupun perkembangan pengelolaannya. Sampai sekarang selain mempunyai kantor pusat di Jl. Pemuda No. 101 Demak, BMT MADE juga mempunyai 6 Cabang yang tersebar di Pasar Bintoro, Karanganyar, Wonosalam, Gajah, Dempet, dan Guntur.

Kedua, BMT Ben Makmur. BMT ini didirikan pada tahun 2001 dengan SK Badan Hukum nomer: 01/BH.1103/X/2001 di desa Kenduren Kecamatan Wedung. BMT Ben Makmur mempunyai visi, Membangun Umat Meraih Makmur, dengan berlandaskan filosofi, ingin menjadikan umat Islam tanpa terkecuali (Profil BMT Ben Makmur, 2015). Visi dan 
filosofi ini kemudian dikembangkan dalam misi dan program kerja yang mendukung produk BMT Ben Makmur.

Perkembangan BMT Ben Makmur sangat bagus, dengan prinsip kebersamaan pengelola mampu meningkatkan aset BMT. Pada awal berdiri, BMT Ben Makmur hanya mempunyai modal 40 juta rupiah dari simpanan anggota pendiri, setelah sekian lama, pada akhir tahun 2014 aset BMT Ben Makmur sudah mencapai 7 Milyar rupiah. Dari tahun ke tahun asset dan omsetnya selalu mengalami kenaikan. Hal ini karena kerjasama antara pengelola, pengurus, dan pengawas, serta didukung kepercayaan dari masyarakat terhadap BMT Ben Makmur.

Ketiga, BMT Assalam. BMT ini berdiri pada tanggal 28 Oktober 2004 dengan SK Badan Hukum nomor: 68/BH.Kop.1103/X/2004. BMT Assalam berkedudukan di Desa Mangunrejo Rt/Rw 01/01 Kecamatan Kebonagung Kabupaten Demak. Tepatnya di Jalan Raya Demak-Godong km. 01 Godong(Profil BMT Assalam, 2015). Pendirian BMT Assalam ini dilatarbelakangi keinginan untuk memenuhi kebutuhan masyarakat Kebonagung Demak dan membantu masyarakat dalam meningkatkan kesejahteraan dan ekonominya.

Adanya keinginan untuk membantu sesama, didukung oleh semangat dari seluruh komponen masyarakat, menjadikan BMT Assalam ini cepat berkembang. Berdiri tahun 2004 dengan fasilitas yang sederhana, gedung dan sarana prasarana yang seadanya, ternyata mengalami kemajuan yang sangat pesat. Pada tahun 2011 telah dibangun gedung baru bertingkat dengan fasilitas standar nasional sebagai lembaga keuangan yang bonafit. BMT ini memberikan pelayanan kepada masyarakat terkait dengan Keuangan Syari' ah yang berupa Assiba, Simjaka, Tarissa, dan kerjasama dengan Kementerian Agama dalam pelaksanaan Tabungan Haji dan Pendaftaran Haji. Sekarang ini BMT Assalam telah membuka kantor Cabang Kramat dan Cabang Mangunrejo.

\section{Pandangan Pengelola BMT tentang Regulasi ZISWAF}

Permasalahan yang perlu dikaji berkaitan dengan regulasi tentang ZISWAF adalah kepastian hukum dan produk Perundang-undangan. Sangat penting untuk melihat secara cermat relevansi dan kontribusi konteks sosial-politik untuk memenuhi tujuan-tujuan legislasi, dan kaitannya dengan 
berbagai kegiatan ZISWAF. Demikian juga, bagaimana kontribusi konfigurasi politik bagi pembentukan dan peningkatan konstruksi hukum yang dapat menopang pelaksanaan ZISWAF agar bisa meningkatkan kesejahteraan dan pemberdayaan ekonomi umat.

Kebijakan tentang regulasi zakat di Indonesia dimulai dari Peraturan Menteri Agama Nomor 4 Tahun 1968 tentang pembentukan Badan Amil Zakat dan Peraturan Menteri Agama Nomor 5 Tahun 1968 tentang pembentukan Baitul Mal (Balai Harta Kekayaan) di Tingkat Pusat, Propinsi dan Kabupaten/ Kotamadya. Kemudian beberapa hari setelah itu, pada peringatan Isra' Mi'raj di Istana Negara pada tanggal 22 Oktober 1968, Presiden Soeharto menganjurkan untuk menghimpun zakat secara sistematis dan terorganisir melalui Badan Amil Zakat Nasional yang dipelopori oleh pemda DKI. Sehingga saat itu berdirilah Badan Amil Zakat, Infak dan Sedekah (BAZIS) di seluruh penjuru nusantara.

Sejak tahun 1968 itu, umat Islam Indonesia telah berjuang untuk memperkuat regulasi tentang zakat. Keinginan tersebut terjawab sudah dengan lahirnya UU no 38 tahun 1999 tentang pengelolaan zakat, meskipun masih juga belum memuaskan semua pihak, namun paling tidak dengan adanya UU tersebut usaha untuk meningkat kesejahteraan umat melalui jalur zakat mulai terkuak. Dengan adanya UU tersebut, dana yang dikumpulkan berupa ZIS dapat dikelola lebih efektif dan efesien melalui lembaga khusus yang telah disahkan pemerintah, yakni Badan Amil Zakat (BAZ) atau Lembaga Amil Zakat (LAZ). BAZ merupakan lembaga pengumpul zakat yang dibentuk pemerintah sedangkan LAZ lebih sebagai lembaga pengumpul zakat yang pembentukannya diprakarsai oleh masyarakat. BAZ yang mempunyai wilayah kerja nasional disebut dengan BAZNAS. BAZNAS adalah institusi yang punya posisi kuat karena di samping disebut dalam UU pengelolaan zakat, juga pembentukannya ditetapkan dengan keputusan presiden (Keres) nomor 8 tahun 2001.

Pengelolaan zakat semakin tertata setelah terbitnya Undang-undang Nomor 38 Tahun 1999 Tentang Pengelolaan Zakat. Disahkannya UU itu, sedikit banyak tak lepas kaitannya dengan peran dan eksistensi LPZ non-pemerintah. Karena dalam UU itu, keberadaan LPZ non-pemerintah diakui eksistensinya. 
Pada saat yang bersamaan, dengan kelahiran UU No. 38 tahun 1999, di masyarakat sendiri lahir sebuah lembaga yang khusus berkiprah dalam penyiapan SDM LPZ. Maka di awal tahun 2000, lembaga bernama Institut Manajemen Zakat (IMZ) itu lahir.

Regulasi zakat semakin kuat dengan turunnya UU Nomer 23 Tahun 2011. Dalam kontek Lembaga Keuangan Syariah, Undang-undang ini sangat strategis, karena: pertama, dengan adanya persyaratan sebagai lembaga organisasi Islam (berstatus hukum resmi), tentu hal ini membuat BAZNAS dan LAZ harus memiliki sistem keuangan Islam yang bagus. Kedua, bertambahnya DPK bank syariah. Ketiga, bisa menambah angka market share dan assetLembaga Keuangan Syariah. Keempat, Lembaga Keuangan Syariah bisa membuat gerai pembayaran zakat dengan sistem setor maupun ATM (UPZ). Kelima, dana zakat yang begitu besar, bisa dikelola oleh Lembaga Keuangan Syariahuntuk hal yang lebih produktif dan untuk pemberdayaan ekonomi umat.

Terkait dengan Perundang-undangan Zakat,pengelola BMT se-Kabupaten Demak memandang perlunya penyempurnaan Undang-undang Zakat, terutama mengenai pengaturan pengurangan pajak dengan zakat. Memang dari segi peruntukannya, ada perbedaan antara zakat dan pajak. Zakat merupakan manifestasi pengabdian kepada tuhan untuk kesejahteraan masyarakat sedangkan pajak adalah bentuk kepatuhan kepada pemerintah (ulil amri). Tetapi keduanya sangat mungkin untuk disinergikan.Namun selama ini zakat baru mengurangi penghasilan kena pajak (PKP), belum sampai pada mengurangi pajak itu sendiri. Harapan para pengelola BMT, zakat bisa mengurangi pajak, sehingga ketika seorang Muslim mengeluarkan zakat, maka pajak yang dibayarkan terkurangi dari zakat yang dikeluarkannya.

Persoalan lain yang menurut para pengelola krusial adalah adanya kebijakan bahwa BAZNAS merupakan satusatunya lembaga yang berhak mengeluarkan Nomor Pokok Wajib Zakat (NPWZ) dan BAZNAS mengambil wilayah garapan lembaga pengelola zakat yang telah dulu muncul. Lembaga yang ditunjuk untuk mengeluarkan bukti setor zakat oleh menteri agama adalah Badan Amil Zakat Nasional (Baznas) sesuai dengan surat nomor MA/422/2002. Menurut 
mereka, BAZNAS hendaknya hanya sebagai pengontrol nomor pokok wajib zakat, sedangkan teknis untuk mendapatkan NPWZ (Nomor Pokok Wajib Zakat) itu bisa dari BAZ maupun dari LAZ.

Selain itu, menurut pengelola BMT se-Kabupaten Demak, yang perlu ditambahkan dalam Undang-undang Zakat adalah sanksi bagi orang yang sudah berkewajiban zakat (muzakki) yang tidak mengeluarkan zakat. Karena dengan adanya sanksi tersebut, penggalangan dana zakat akan efektif. Pendapat ini merujuk pada kebijakan Khalifah Abu Bakar, yang memerangi kaum Muslimin yang menolak membayar zakat.

Sedangkan regulasi tentang wakaf di Indonesia dimulai dengan keluarnya Peraturan Departemen Agama pada 22 Desember 1953 tentang prosedur pemberian tanah wakaf, yang kemudian diatur kembali oleh Surat Edaran Departemen Agama No. 5/D/1956. Kemudian, diterbitkannya Undang-undang Nomor 5 Tahun 1960 tentang Peraturan Dasar Pokok-Pokok Agraria. Dalam Undang-undang ini, aset wakaf mendapatkan dasar hukum yang tetap, di mana negara secara resmi menyatakan perlindungan terhadap harta wakaf. Dalam Pasal 49 ayat 3 disebutkan bahwa perwakafan tanah milik dilindungi dan diatur menurut peraturan pemerintah. Perlindungan atas aset wakaf juga dipertegas kembali dalam Peraturan Pemerintah No. 10 Tahun 1961 tentang Pendaftaran Tanah. Peraturan ini meningkatkan penertiban sertifikasi tanah atas tanah wakaf yang telah diikrarkan.

Setelah mendapatkan jaminan perlindungan dari pemerintah, eksistensi wakaf semakin mendapatkan tempat dengan terbitnya Peraturan Pemerintah No. 28 Tahun 1977 tentang Perwakafan Tanah Milik, yang memuat unsur-unsur substansi dan teknis perwakafan. Terbitnya Peraturan Pemerintah No. 28 Tahun 1977 ini menciptakan pembaruan yang sangat penting dalam pengelolaan harta wakaf. Peraturan ini memberikan legalitas bagi bolehnya pertukaran harta wakaf setelah mendapatkan izin dari Menteri Agama. Aturan lain yang membawa pembaruan dalam pengelolaan wakaf adalah Instruksi Presiden No. 1 Tahun 1991 tentang Kompilasi Hukum Islam (KHI).

Saat ini telah lahir Undang-undang No. 41 tahun 2004 tentang wakaf dengan tujuan pokok untuk mendorong kemajuan 
pengelolaan wakaf di Indonesia. Dengan Undang-undang ini, sektor wakaf diharapkan mampu berfungsi sedemikian rupa, sehingga mendukung kesejahteraan sosial-ekonomi umat Islam. Apalagi para ulama dan pemerhati masalah-masalah wakaf dari berbagai ormas Islam, baik Nahdlatul Ulama (NU), Muhammadiyah, maupun ormas-ormas Islam lainnya mendukung proses legislasi wakaf ini dengan sunggungsungguh. Konteks kelahiran dan motif terpenting regulasi wakaf tersebut adalah untuk peningkatan kesejahteraan ekonomi dan penguatan masyarakat sipil dengan memanfaatkan sumbersumber alternatif yang potensial dalam wakaf (Najib dan Ridwan, 2006).

Pentingnya regulasi Perundang-undangan wakaf ini bisa kita analisis dari beberapa pasal dalam Undang-undang No. 41 tahun 2004. Dalam pasal 4 dan pasal 5 dinyatakan bahwa wakaf bertujuan memanfaatkan harta benda wakaf sesuai dengan fungsinya; wakaf berfungsi mewujudkan potensi dan manfaat ekonomis harta benda wakaf untuk kepentingan ibadah dan untuk memajukan kesejahteraan umum. Juga dalam pasal 12 mengenai peruntukan harta benda wakaf disebutkan bahwa dalam rangka mencapai tujuan dan fungsi wakaf, harta benda wakaf hanya dapat diperuntukkan bagi: 1) sarana dan kegiatan ibadah; 2) sarana dan kegiatan pendidikan serta kesehatan; 3) bantuan kepada fakir miskin, anak terlantar, yatim piatu, beasiswa; 4) kemajuan dan peningkatan ekonomi umat; dan 5) kemajuan kesejahteraan umum lainnya yang tidak bertentangan dengan syariat dan peraturan Undang-undang yang berlaku.

Menurut pengelola BMT se-Kabupaten Demak, UndangUndang Nomor 41 Tahun 2004 tentang Wakaf juga demikian. Undang-Undang Wakaf ini sudah mengalami kemajuan dan menyempurnakan peraturan perundang-undangan tentang wakaf sebelumnya. Setidak-tidaknya menurut mereka ada beberapa catatan terkait Undang-undang wakaf tersebut, di antaranya Undang-undang wakaf bertujuan menciptakan tertib hukum dan administrasi wakaf guna melindungi harta benda wakaf. Dalam undang-undang ditetapkan bahwa perbuatan hukum wakaf wajib dicatat, dituangkan dalam Akta Ikrar Wakaf (AIW), didaftarkan dan diumumkan dalam media yang diatur dalam perundangundangan. 
Menurut pengelola BMT, Undang-undang wakaf juga bertujuan untuk memperluas ruang lingkup objek wakaf. Dalam Undang-undang wakaf ditetapkan bahwa benda wakaf boleh benda bergerak dan tidak bergerak, serta benda yang berwujud (empiris) dan tidak empiris, seperti: wakaf uang, logam mulia, surat berharga, kendaraan, hak kekayaan intelektual, dan hak sewa. Selain itu, Undang-undang wakaf bertujuan untuk memperluas ruang lingkup penggunaan wakaf. Dalam Undangundang wakaf ditetapkan bahwa harta benda wakaf tidak semata-mata digunakan untuk kepentingan ibadah dan sosial, melainkan juga diarahkan untuk memajukan kesejahteraan umum dengan cara menggali potensi dan manfaat ekonomi harta benda wakaf.

\section{Pandangan Pengelola BMT tentang Filantropi Islam}

Filantropi Islam semakin pesat perkembangannya justru ketika krisis ekonomi mendera bangsa Indonesia dan terbukanya iklim demokrasi di era reformasi. Era ini merupakan puncak dari institusionalisasi filantropi Islam dengan banyak dikeluarkannya undang-udang dan peraturan pemerintah mengenai pelaksanaan filantropi Islam. Dua undang-undang yang sangat strategis adalah Undang-undang Zakat (1999 dan 2011) dan Undangundang Wakaf (2004) yang mengatur pelaksanaan zakat dan wakaf. Selain itu, muncul keinginan masyarakat untuk mengelola zakat secara profesional dengan membentuk lembaga zakat, baik yang dibentuk oleh pemerintah (BAZIS) maupun yang dibentuk oleh masyarakat (LAZIS). Sementara itu tumbuh pula inisiatif dari kalangan swasta untuk mengumpulkan dan mendistribusikan dana zakat dari masyarakat (Irfan Abu Bakar (ed.), 2006).

Selain dua lembaga di atas, ada beberapa lembaga baru yang bergerak dalam filantropi Islam, di antaranya adalah Lembaga Keuangan Mikro Syariah yang terlembagakan dalam BMT. Semua lembaga tersebut memanfaatkan dana zakat, infak, sedekah, dan wakaf untuk tujuan-tujuan keadilan sosial.Praktik filantropi masyarakat Muslim dalam bentuk zakat bertujuan memperkuat kohesi sosial, karena zakat bertujuan meneguhkan hubungan di antara muslim melalui praktik filantropi orang kaya terhadap orang miskin. Pada level kognitif, zakat yang ditunaikan menurut ajaran Islam, akan menyucikan muzakki 
(orang yang mengeluarkan zakat). Sedangkan bagi mustahiq (orang yang berhak menerima zakat), zakat akan menyucikan mereka dari bersarangnya sifat kebencian dan kecemburuan kepada orang kaya.

Begitu juga wakafyang telah menjelma dalam ribuan masjid, mushalla, pesantren, madrasah, sekolah, rumah sakit, dan lain sebagainya (Shabri, 2008). Wakaf merupakan pranata keagamaan dalam Islam yang memiliki keterkaitan langsung secara fungsional dengan upaya pemecahan masalah-masalah sosial dan kemanusiaan, seperti pengentasan kemiskinan, jaminan sosial (Nafis, 2009) peningkatan sumber daya manusia dan pemberdayaan ekonomi umat. Hal ini karena wakaf sesungguhnya memiliki elan besar dalam mewujudkan tata sosial yang berkeadilan. Wakaf sebagai kekuatan penopang produktifitas umat Islam dapat dilihat dari akumulasi potensi besar dari aset wakaf (Qahaf, 2006).

Para pengelola BMT se-Kabupaten Demak, baik pendiri, manajer, staf, maupun donatur sepakat tentang pentingnya praktik filantropi Islam. Tentang zakat misalnya, filantropi dalam bentuk zakat berpotensi memberikan kontribusi pada penguatan solidaritas sosial dan rasa kepemilikan atas kesatuan umat. Tindakan berzakat merupakan bentuk nyata dari komitmen seorang Muslim dan loyalitasnya terhadap agama dan nilai-nilai keadilan sosial. Hal ini bisa direalisasikan manakala zakat yang diberikan kepada fakir miskin bersifat produktif, mengangkat taraf hidup dan kesejahteraan kaum fakir miskin.

Mereka juga mempunyai pandangan yang progresif. Zakat produktif menurut pengelola BMT akan betul-betul berdampak positif manakala ada pendampingan dari muzakki atau amil zakat. Contoh ketika berbicara tentang kemiskinan masyarakat petani, misalnya, solusinya tidak sekadar memberikan perangkat-perangkat pertanian yang dapat meningkatkan produktivitas hasil tani, atau memberikan penyuluhan cara bercocok tanam yang benar. Mengatasi kemiskinan petani hendaknya juga mempertimbangkan kebijakan pemerintah tentang pertanian; apakah sudah berpihak pada petani-petani gurem dengan memproteksi mereka dari ketergantungan terhadap tengkulak, atau memproteksi mereka dari kesewenang-wenangan pasar yang sering tidak adil dalam 
menentukan harga gabah dari petani, sementara tidak membiarkan harga pupuk terus meningkat.

Dalam hal apa saja yang wajib dizakati, menurut mereka juga perlu ada pembaruan, seperti zakat profesi yang belum dikenal pada zaman Nabi. Zakat profesi ini, menurut mereka bisa dianalogikan dengan perdagangan yang kadar zakatnya 2,5 $\%$ atau dengan zakat pertanian yang kadar zakatnya $5 \%$. Menurut pengelola BMT ini, tidak adil dong para petani dan pedagang yang penghasilannya tidak seberapa harus mengeluarkan zakat, sedangkan mereka yang mempunyai profesi dengan penghasilan tinggi tidak dikenai zakat.

Menurut mereka, penghitungan nisab dan pengambilan zakat untuk karyawan dan profesi tertentu yang paling praktis dilakukan dengan cara penghitungan bruto, karena bisa langsung diambil dari gaji. Selain itu, mereka juga setuju apabila pertanian non makanan pokok, saham, obligasi, dan surat berharga, juga merupakan pendapatan yang wajib dizakati. Argumentasinya karena semua yang menghasilkan dan bernilai ekonomi, harus dikeluarkan zakatnya.

Sedangkan terkait dengan ptraktik filantropi dalam bentuk wakaf, para pengelola BMT se-Kabupaten Demak sepakat membolehkan wakaf produktif, wakaf dalam bentuk uang, dari sumber individu maupun kolektif. Wakaf ambulans dan benda-benda bergerak lainnya juga menurut mereka diperbolehkan. Demikian juga wakaf saham, obligasi, surat berharga, dan bahkan hak kekayaan intelektual juga boleh menurut mereka. Ini sejalan dengan semangat wakaf sebagai paraktik filantropi yang mampu mengentaskan kemiskinan dan meningkatkan kesejahteraan umat.

Namun, pemahaman wakaf uang menurut mereka sedikit berbeda dengan konsep wakaf uang yang ada dalam Undangundang Nomor 41 Tahun 2004 tentang Wakaf dan fatwa MUI. Wakaf uang menurut Undang-undang dan Fatwa MUI adalah wakaf dalam bentuk uang yang diserahkan kepada Lembaga Keuangan Syari'ah Penerima Wakaf Uang (LKSPWU), kemudian Badan Wakaf Indonesia (BWI) mengeluarkan setifikat wakaf uang atas nama wakif. Uang ini harus tetap utuh selamanya, abadan lil abad, sedangkan hasil investasinya itulah yang dimanfaatkan untuk kepentingan umum. Sedangkan wakaf uang menurut pengelola BMT, sebenarnya bukan wakaf uang 
melainkan wakaf dengan uang. Tujuan wakaf adalah terealisasinya harta dan benda yang menjadi kesepakatan antara wakif dan nadzir, sedangkan media transaksinya dengan uang.

Terlepas dari perbedaan persepsi tentang wakaf uang ini, potensi pengembangan wakaf uang juga sangat besar. Mustafa Edwin Nasution pernah membuat asumsi bahwa penduduk muslim kelas menengah di Indonesia sebanyak 10 juta jiwa dengan penghasilan rata-rata antara 0,5 juta-10 juta perbulan. Menurut perhitungan angkanya, ini merupakan potensi yang sangat besar. Misalnya, jika warga yang berpenghasilan Rp 0,5 juta sebanyak 4 juta orang, dan setiap tahun masing-masing mewakafkan hartanya $\mathrm{Rp} 60$ ribu, maka setiap tahun akan terkumpul Rp 240 miliar. Jika warga yang berpenghasilan 1-2 juta sebanyak 2 juta orang, dan setiap tahun masing-masing mewakafkan hartanya Rp 120 ribu, maka akan tekumpul dana sebanyak 360 miliar. Jika warga yang berpenghasilan 2-5 juta sebanyak 2 juta orang, dan setiap tahun masing-masing mewakafkan hartanya Rp 600 ribu, maka akan tekumpul dana sebanyak 1,2 triliun. Jika warga yang berpenghasilan 5-10 juta sebanyak 1 juta orang, dan setiap tahun masing-masing mewakafkan hartanya Rp 1,2 juta, maka akan tekumpul dana sebanyak 1,2 triliun. Jadi dana yang terkumpul mencapai 3 triliun. Ini merupakan aset yang sangat potensial. (Departemen Agama, 2007)

\section{Pengelolaan ZISWAF Untuk Pemberdayaan Ekonomi Umat}

Di tengah problem sosial masyarakat dan tuntutan kesejahteraan ekonomi akhir-akhir ini, eksistensi ZISWAF menjadi sangat strategis. Selain sebagai salah satu aspek ajaran Islam yang berdimensi spiritual, zakat, infak, shadaqah, dan wakaf juga merupakan ajaran yang menekankan pentingnya kesejahteraan ekonomi dan dimensi sosial.ZISWAF merupakan pilar penyangga bagi tegaknya institusi-institusi sosialkeagamaan masyarakat muslim selama berabad-abad. Hal itu dilakukan melalui penyediaan dana dan sarana pendukung bagi kegiatan-kegiatan ritual keagamaan, pendidikan, pengembangan ilmu pengetahuan, seni dan budaya.

Apabila dikelola secara produktif, akan mampu menjalankan fungsi yeng lebih lagi, misalnya penyediaan sarana umum, pemberdayaan ekonomi, dan sebagainya. Tujuan-tujuan 
ini sejalan dengan paradigma kemaslahatan yang menjadi orientasi dari syariat Islam. Lembaga yang mengelola ZISWAF juga mempunyai peran dan fungsi yang signifikan sebagai instrumen pengembangan ekonomi. Dalam jangkauan yang lebih luas, kehadiran mereka dapat pula dirasakan manfaatnya untuk meningkatkan taraf hidup masyarakat di bidang ekonomi, terutama sekali jika wakaf dikelola dengan manajemen yang rapi, teratur dan profesional.

Para pengelola BMT se-Kabupaten Demak juga menyadari peran penting pengelola ZISWAFyang semakin luas, tidak hanya sekedar menjaga dan melakukan hal-hal yang bersifat rutinitas, melainkan juga mencari inovasi-inovasi baru dalam rangka mengembangkan dan memberdayakan aset ZISWAF tersebut. Untuk itu, perlu ada upaya perbaikan yang bertujuan untuk membenahi manajemen dan pengelolaan ZISWAF. Karena jika dikelola secara produktif akan berkembang baik manajemennya maupun investasinya.

Ada tiga sistem pengelolaan ZISWAF yang dilakukan pengelola BMT se-Kabupaten Demak. Pertama, sistem pengelolaan satu arah. Dalam sistem ini dana masyarakat yang diterima didistribusikan secara serentak kepada masyarakat dengan skala prioritas mikro ekonomi. Kedua, sistem pengelolaan umpan balik feed back). Dalam sistem ini, pengelola BMT sebagai fasilitator bagi masyarakat yang membutuhkan pendanaan, sehingga distribusi dana diupayakan sebagai modal pengembangan usaha menuju kemandirian. Melalui cara ini, diperoleh laba bersih sebagai pengembangan dari modal awal. Ketiga, dengan sistem pilot project. Sistem ini direncanakan dengan melibatkan perorangan atau lembaga yang sifatnya terbatas untuk mengetahui tingkat efektifitas dari sistem yang dilaksanakan.

Sedangkan pemberdayaan ZISWAF yang dilakukan oleh pengelola BMT adalah: pertama, pemberdayaan sosial dengan cara penyaluran dana untuk fakir miskin langsung berupa santunan, penyaluran untuk sarana prasarana pendidikan, penyaluran dana untuk yatim piatu, penyaluran untuk sarana ibadah, dan untuk kegiatan sosial lainnya. Kedua, pemberdayaan untuk pengembangan sumber daya manusia. Caranya dengan memberikan beasiswa kepada putra-putri kaum dhuafa, mengadakan pelatihan ketrampilan, dan pengadakan pengajian- 
pengajian secara berkala. Ketiga, dengan model pemberdayaan ekonomi yang terdiri dari: penyaluran dengan mudharabah muqayyadah (produk pembiayaan dengan para pengusaha yang amanah untuk mengelola dana dengan sistem bagi hasil guna memperbesar manfaat yang diterima oleh mustahik), dengan penyaluran wadi'ah muqayyadah (produk pemberdayaan para dhuafa oleh BMT dengan cara memberikan hewan ternak yang hasilnya dinikmati oleh peternak dhuafa), dan pemberdayaan dengan pinjaman lunak tanpa bagi hasil, khususnya bagi pedagang kecil.

Menurut pengelola BMT, sektor yang menjadi skala prioritas distribusi adalah sektor pemberdayaan ekonomi dan pembinaan keagamaan para mustahik. Hal ini sejalan dengan kebijakan penyaluran bantuan ZIS dan hasil dari pengelolaan wakaf produktif kepada mustahik, dengan berdasarkan pada pertimbangan kesalehan. Mereka juga melakukan pengawasan terhadap para mustahik, karena mereka sadar bahwa tidak ada program yang sukses tanpa control dari masyarakat. Demikian juga, yang tidak kalah pentingnya adalah program pelatihan untuk pemberdayaan zakat produktif dan wakaf produktif, baik kepada mustahik, staf maupun manajer cabang. Kebutuhan akan pelatihan ini terutama karena pengelolaan ZISWAF di cabangcabang masih dirangkap oleh pengelola Baitut Tamwil. Dengan cara ini mereka yakin BMT akan menjadi pioner dalam pengelolaan ZISWAF dan pengembanngan filantropi Islam.

\section{PENUTUP}

Potensi pengembangan filantropi Islam sangat besar dalam bentuk kedermawanan umat Islam melalui zakat, infak, shadaqah, dan wakaf. Hasil survei menunjukkan bahwa hampir semua masyarakat Muslim Indonesia (99\%) pernah berderma. Sejalan dengan semangat kedermawanan umat Islam, filantropi Islam di Indonesia juga tengah mengalami perkembangan signifikan yang ditandai dengan meningkatnya antusiasme umat dalam berfilantropi dan dipengaruhi oleh revitalisasi visi dunia filantropi Islam, yang mencoba mentransformasikan paradigma lama filantropi dengan paradigma baru yang lebih kreatif dan inovatif. Filantropi Islam dalam bentuk ZISWAF apabila dikelola secara produktif, akan mampu menjalankan fungsi yeng 
maksimal, seperti penyediaan sarana umum, pemberdayaan ekonomi, dan sebagainya.

Pengelolaan dan pemberdayaan ZISWAF yang dilakukan pengelola BMT se-Kabupaten Demak sudah sangat bagus dan tertata secara sistematis. Indikatornya adalah: adanya sistem pengelolaan satu arah, sistem pengelolaan umpan balik (feed back) dandengan sistem pilot project. Sedangkan indikator pemberdayaan ZISWAF yang dilakukan oleh pengelola BMT adalah: adanya pemberdayaan untuk pengembangan sumber daya manusia, dengan model pemberdayaan ekonomi,dan pemberdayaan sosial dengan cara penyaluran dana untuk fakir miskin langsung berupa santunan, penyaluran untuk sarana prasarana pendidikan, penyaluran dana untuk yatim piatu, penyaluran untuk sarana ibadah, dan untuk kegiatan sosial lainnya. 


\section{DAFTAR PUSTAKA}

Abu Bakar, Irfan dan Chaidar S. Bamualim (ed.). (2006). Filantropi Islam dan Keadilan Sosial: Studi tentang Potensi, Tradisi, dan Pemanfaatan Filantropi Islam di Indonesia, kerjasama The Ford Foundation dan CSRC.

Al-Makassari, Ridwan. (2006). Pengarusutamaan Filantropi Islam untuk Keadilan Sosial di Indonesia; Proyek yang Belum Selesai: Jurnal Galang, 1(3), April.

Bamualim, Chaidar S. dan Irfan Abu Bakar (ed.). (2005). Revitalisasi Filantropi Islam: Studi Kasus Lembaga Zakat dan Wakaf di Indonesia, Pusat Bahasa dan Budaya (PBB) UIN Jakarta, Jakarta.

Ilchman, Warren F., Stanley N. Katz, dan Edward L. Queen II (ed.). (2006). Philanthropy in the World Traditions (Filantropi di Berbagai Tradisi Dunia), Jakarta: Center for the Study of Religion and Culture (CSRC),

Klein, Kim. (2001). Fundraising for Social Change, Fourth Edition, Oakland California: Chardon Press.

Nafis, Cholil. (2009). Wakaf Uang untuk Jaminan Sosial. Jurnal al-Awqaf, II(2).

Qahaf, Mundzir. (2006). Al-Waqf Al-Islamy; Tațawwuruhu, Idaratuhu, Tanmiyyatuhu, Syiria: Dar Al-Fikr Damaskus.

Qardhawi, Yusuf. (2000). Fiqih Zakat: Dirasah Muqaranah li Ahkamiha wa Falsafatiha fî Dhau'i al-Quran wa Sunnah, Beirut Libanon: Mu'assasah ar-Risalah, cet 24.

Shabri, Ikrimah Sa'id. (2008). Al-Waqf Al-Islamy: Baina anNazhriyyah wa at-Tathbîq, Dar an-Nafais, Yordan.

Widodo, Hertanto Ak.dkk. (1999). Panduan Praktis Operasional Baitul Mal wat Tamwil, Bandung.

Zahrah, Abu. (2005). Muhadlarah fî al-Waqf, Dar al-Fikr al'Arabi, Cairo. 